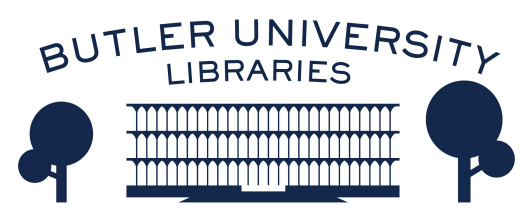

Journal of Hindu-Christian Studies

Volume 3

Article 7

January 1990

\title{
Book Review: "In Search of Self in India and Japan: Toward a Cross-Cultural Psychology"
}

Harold Coward

Follow this and additional works at: https://digitalcommons.butler.edu/jhcs

Part of the Religion Commons

\section{Recommended Citation}

Coward, Harold (1990) "Book Review: "In Search of Self in India and Japan: Toward a Cross-Cultural Psychology"," Journal of Hindu-Christian Studies: Vol. 3, Article 7.

Available at: https://doi.org/10.7825/2164-6279.1030

The Journal of Hindu-Christian Studies is a publication of the Society for Hindu-Christian Studies. The digital version is made available by Digital Commons @ Butler University. For questions about the Journal or the Society, please contact cbauman@butler.edu. For more information about Digital Commons @ Butler University, please contact digitalscholarship@butler.edu. 
complexities that need to be taken into account in looking into that most intricate of all subjects - the meeting of person with person, tradition with tradition, faith with faith" (p. 113).

John B. Carman

Center for the Study of World Religions

Harvard Divinity School

Cambridge, Massachusetts

In Search of Self in India and Japan: Toward a Cross-Cultural Psychology. Dr. Alan Roland. Princeton, New Jersey: Princeton University Press, 1988, xxxii + 386p.

Roland, a psychoanalyst, compares the extended familial-self typical of Indian and Japanese experience with the individualized self-concept of America. This difference is significant for one's conception of marriage, social relations, art, time and space, subject-object relations and the spiritual goal. Freudian categories (egoideal, superego, etc.) are adopted but contextualized through clinical work with Indian and Japanese patients. Roland demonstrates convincingly that self-concept varies radically according to culture. Therefore, application of Freudian or other Western categories directly to Eastern experience is invalid. Psychological structuring is shown to be embedded in the distinct views of human nature, social patterns and childrearing practices of the various cultures.

This book adds crucial psychological dimensions to our study of Eastern philosophy and religion. It catches the vital nuances of self-experience that escape philosophical and historical approaches. It works well in senior undergraduate and graduate classes and is essential for libraries. The treatment of Japan, however, is weak. The analysis of Indian experience is overly influenced by Vedanta philosophy and shows no sensitivity to the cultural diversity within India. Yet, in spite of these limitations, the book opens important new ground.

Harold Coward

University of Calgary

Calgary, Canada

River of Compassion: A Christian Commentary on the Bhagavad Gĩtā. Bede Griffiths. Warwick, N.Y.: Amity House, 1987, 328p., \$11.95.

Another commentary on the Gitāa There can be little doubt but that in India-both in ancient and in modern times-and in the West-throughout the present century - there has been a literal plethora of bhasyas on this spiritual classic. Arguably the Git $\bar{a}$ is one of, if not the most popular of the religious texts to come from the Hindu tradition. However, as Father Bede rightly points out in his 